\title{
STRATEGIC SUBMISSIONS BY THE ARMENIANS
}

By examining the establishment of the Mongol protectorate in nonMongol lands, one can see that a conventional set of demands was made for newly-conquered peoples or lands. These demands included the local king's or lord's personal presentation at the Mongol court; the delivery of hostages, usually sons of the nobility; the provision of armed forces; the submission of household registers and payment of taxes; and the provision of stations (yams) for the Mongol governors. The first of these requirements, the personal visits of Armenian lords to the Mongol court represents the most interesting matter along with their policy towards the new reality of the Mongol presence in their lands between 1236 and 1256 and their individual and collective decisions to ally with the Mongols making explicit use of this cooperation. Conflicts that existed among the Armenian princes which led to local revolts against the Mongol regime and the Georgian crown in 1245 and 1259-1261, did not hinder the actual factors to facilitate a Mongol-Armenian alliance.

\section{Individual Submissions and Contacts of Greater Armenian Princes with the Mongol Khans and Il-Khans}

During and after the completion of the Mongol conquest of the Caucasus, some of the Georgio-Armenian princes, recognising the authority of the Mongols, decided to support the Mongol regime and in this way to secure their rights and lands. One of the key decisions of the lords, either on Mongol demand or on a voluntary basis, was to visit the Mongol Great Khans. This factor is identified by Dr. Bedrosian as one of the methods of the 'de-nakhararisation' of Greater Armenia, by which the Mongols aimed in various ways to remove powerful men from the Caucasus. ${ }^{1}$ This statement is debatable, firstly because the process of 'de-nakhararisation' had been

\footnotetext{
${ }^{1}$ Bedrosian, 1979:195.
} 
started before the Mongols' arrival. ${ }^{2}$ Secondly, it only reflects external factors of the process; in my opinion, there was an internal factor as well. Apart from being required by the Mongol overlords, the travels of the Armenian lords to Mongolia also aimed to resolve personal or local matters and the far-reaching result of these journeys was to remove their own potential Georgian or Armenian competitors from the political arena, an aim which perfectly suited Mongol policy.

Awag (d. 1250), the son of Iwanē Zak'arian (d. 1234), was the first Caucasian noble to submit to the Mongols. Kirakos Gandzakets'i gives a detailed account of how this happened. ${ }^{3}$ In 1236, Awag, seeing that the Mongols continued to besiege his stronghold, Kayen, even after taking his daughter and gifts, sent one of Khachen's nobles, Grigor called Tghay to meet the Mongol leader Chormaghan, who was camped at the time by the shores of Lake Geghark'unik' (Sevan). When the great Commander Chormaghan heard about Awag's intention to submit, he ordered his troops to stop besieging the fortress. Soon after, Awag was received by Chormaghan. An interesting conversation between Awag and Chormaghan followed, which can be interpreted from different angles. I am interested in seeing how the interaction between the conqueror and his subject proceeded. The Mongol commander asked Awag why he had not come earlier, when he crossed the borders of his land. Awag replied:

That time you were remote, my father was alive and he served you [the Mongols] in all ways, and since he has died, I will serve you according to my ability, and now, as you have come to my land, here I come to you. ${ }^{4}$

As has been said previously, Awag's father Atabeg Iwanē Zak'arian faced the Mongol advance into Armenia. He fought against Jebe and Sübedei. There is no record in contemporary Armenian sources of the exact relationship between Iwane Zak'arian and the Mongols; however, Awag's answer shows that his father had already given service to the Mongols. Chormaghan told a proverb to Awag: 'I came to the dormer window, you did not come. I came to the door, behold, you have come. ${ }^{5}$ This proverb is associated with a famous Mongolian saying, sükh dalaital üher amrakh (the cow rests until the axe swings),

\footnotetext{
2 Adonts, 1970:183.

${ }^{3}$ Kirakos Gandzakets'i, 1961:254-257.

${ }^{4}$ Ibid., 256. Iwanē Zak'arian died in 1234 (Manandian, 1952:410).

${ }^{5}$ Kirakos Gandzakets'i, 1961:256.
} 
which means 'to rest until real danger comes.' When the Mongol commander ordered a meal in Awag's honour, he sat the latter below all his nobles. Awag was offered a large quantity of meat 'both from clean and unclean animals' and khmuzs (kumis), fermented mare's milk, but Awag said that the Christians were not accustomed to eat such food or to drink such a beverage; they ate meat from permitted animals and drank wine. ${ }^{6}$ Therefore, Chormaghan gave an order to bring what he requested. The next day, Awag was seated above many nobles, and day after day, he was honoured more and more until he sat among the ranks of the great lords. ${ }^{7}$

The plausibility of this conversation is contentious, but surely, Kirakos wants to highlight the pride and bravery of the Armenian prince and the details of his submission. Referring to the customs of the Mongols and Armenians, Kirakos tries to engage with the cultures of both sides and thus to show the diversity of the people coming into contact for the first time. We can assume that the Mongol recognition of Armenian nobility by the Mongols was a very important start in the relationship between conqueror and subject. Perhaps the way Awag was received by the Mongols had a significant influence on the other lords' decision-making.

Indeed, Awag Zak'arian was the first Caucasian lord to exemplify individual submission to the Mongols. This act secured Awag's land. ${ }^{8}$ He obtained a status of invulnerability for all his dominions and established a strong friendship with Chormaghan. In return, Awag was obliged to take his troops with him to march against the city of Ani and to participate in the conquest of the west [Asia Minor]. ${ }^{9}$ After the escape of Queen Rusudan to Swanetia out of fear of the Mongols, Awag became the most influential figure at the Georgian royal court. ${ }^{10} \mathrm{He}$ was de facto ruler of Armenia, and the Mongol administrators sent him to the Great Khan. The exact date of Awag's

${ }^{6}$ Ibid., 256. Friar William of Rubruck gave the same answer to the Mongol host's offer, namely that the Christians do not drink kumis, and that once they had drunk it they would renounce their Christian faith (Rubruck in Komroff, 1989:77). The same answer was given by al-Kāmil Muhammad, the Ayyubid ruler of Mayyāfāriqīn to Mönkge Khan (Jūzjānī, 1970:1266).

7 Kirakos Gandzakets'i, 1961:254-257.

8 Ibid., 257.

9 Awag participated in Baiju's conquest (Kirakos Gandzakets'i, 1961:280).

${ }^{10}$ Ibid., 238. Queen Rusudan, being under constant pressure from the Mongols, took poison voluntarily and left a will entrusting the kingdom to Awag Zak'arian (Kirakos Gandzakets'i, 1961:316). 
journey to Mongolia is not known, although he paid this visit before the replacement of Chormaghan by Baiju, presumably in 1240/1241. According to Kirakos Gandzakets'i, Awag himself was happy to make this journey so that his visit would help the situation in his country. ${ }^{11}$ In fact, the Great Khan, presumably Ögedei Khan, received the prince with affection, gave him a Mongol wife and sent him home. ${ }^{12}$

It is worth mentioning that the practice of giving vassals a Mongol girl in marriage was exercised extensively by Chinggis Khan and his successors. ${ }^{13}$ However, to my knowledge, there are no records in the Armenian historical annals or church council documents about the regulation of Mongol-Armenian marriages. In view of the fact that the children of such marriages were baptised, one can conclude that these mixed marriages were accepted by the Armenian Church. ${ }^{14}$

After his return from the Mongol court, Awag restored his lordship over his dominion. Nevertheless, in 1245, with increasing anarchy caused by tax collectors, as Kirakos Ganzakets'i testifies, Awag fled to Queen Rusudan, who was still living in a fortress. The Mongols considered this action as rebellion, so Awag wrote a letter to the Khan explaining that his action was not a revolt, but that he was only escaping from disorder. A messenger called Tonghus-aqa came from Güyük Khan to Awag with proof of his immunity. In return, Awag was obliged to convince the Queen to submit voluntarily to the Great Khan. ${ }^{15}$ However, Queen Rusudan died in 1245 before this order came; Awag himself died in $1250 .{ }^{16}$

Awag's submission had a domino effect on the other lords. The Armenian princes, such as Shahnshah (d. 1261), the son of Zak'arē, Vahram Gagets'i (fl. 1240-1250) and his son Aghbugha, and Hasan Jalal, the prince of Khachen, all followed his example in 1236.

On seeing that the other lords retained their lands, the Armenian princes of the Orbelian, Pŕoshian, Dop'ian, Vach'utian and Jalalian houses aimed to cooperate with Mongol administrators in order to retain their principalities, which had been under the suzerainty of

11 Ibid., 262.

12 Ibid., 263.

${ }^{13}$ MNT, 2004:78(\$235), 79(\$238-239).

14 Vasil Tatar, the son of Smbat Sparapet by his Mongol wife, was baptised and knighted in 1265 and was a general-in-chief of the Cilician Armenians (Smbat Sparapet in Der Nerssessian, 1973:373-374).

${ }_{15}$ Kirakos Gandzakets'i, 1961:266.

16 Vardan Arevelts'i, 1991:148; Sebastats'i in Hakobyan, 1956:140. 
the Zak'arids during the previous century. ${ }^{17}$ It was understood that they could regain their own land from the Mongol commanders, as mentioned in the previous chapter concerning a deal between Elikum Orbelian and Aslan Noyan. ${ }^{18}$ This desire of the Armenian lords was welcomed by the Mongols who gave them enchü (injü) status, that of the Khan's personally-owned people, which in Orbelian's History of the Siwnik' Province is interpreted as unknnula (tēruni) or lordly. ${ }^{19}$ Although this status meant that the Mongols imposed some direct obligations on these lords, it did give the latter, who had previously allied with the Georgian King, and their lands some privileges, such as immunity in terms of tax and sovereignty vis-à-vis the Mongols. The outcome of this act brought about the detachment of ties they had formed earlier, for the princes started to alter their attachment to the Georgian King, allying themselves with the Mongols.

This was true as well for Hasan Jalal Dawla (d. 1261) of the Khachen province, the next Armenian noble to support the Mongols. Receiving honour and trust from the Mongols, Hasan Jalal arranged his own affairs in practice. According to the Armenian source, he was the one who supported the Mongol elchis, or messengers, and did whatever was possible for them, whether this meant providing food or horses. ${ }^{20}$ Perhaps because of this, or because he exercised some privileges in arranging his own and Mongol affairs, Amir Arghun (d. 1275/1277), the administrator of Mongol taxation, dis-

${ }^{17}$ Hovsep'ean, 1928:16-17. Iwanē Zak'arian granted the Orbelian house the lands in eastern Vayots' Dzor, in Kotayk', Geghark'unik' and Kayen in 1184 (Step'annos Orbelian, 1910:397). In the 1210s, the Pŕosians or Khaghbakeans helped the Zak'arians in the re-conquest of Vayots' Dzor, Bjni and Dvin (Dwin). As a reward, they were given lands in western Vayots' Dzor, Shahapunik', Varazhnunik' and parts of Kotayk and Ayrarat. The head of the Vach'uteants' family, Vach'ē was a loyal follower of Zak'arē who gave him all the districts of Aragatsotn, Shirak, Nig and Anberd as far as Eraskhadzor. Iwanē's sister Dop'i married Hasan, the prince of Arts'akh in eastern Armenia, receiving a large area on the southern shore of Lake Sevan and the district Sot'k in Siwnik'. They were known as Dop'ians'. Another sister of Iwane married Vakht'ang, the lord of Khachen province; the house took on the name of Jalalians after Hasan Jalal (Babayan, 1976:546-550).

${ }^{18}$ Step'annos Orbelian, 1910:402-403.

19 Ibid., 409; For enchü/injü, see Scherbak, 1997:194; cf. Doerfer, 1963(Vol. 1):220-225. The etymology of enchü is Mongolian emčü, which means a private property (Lessing, 1973:635). Shiraiwa suggests that injül injū is Persianised form of the Mongolian emčü and Rashīd al-Din gave the term three meanings, namely 'personal property,' 'crown land' and 'immediate vassal' (Shiraiwa, 1988:371-376).

${ }^{20}$ Kirakos Gandzakets'i, 1961:269, 284. 
liked him and treated him harshly. ${ }^{21}$ In 1251, in order to escape from Amir Arghun, Hasan Jalal paid a visit to Sartakh (r. 1255-1256) of the Golden Horde. ${ }^{22}$ Sartakh took Hasan Jalal to his father, Batu Khan (r. 1205-1255), who returned to Hasan Jalal his patrimony of Ch'araberd, Akanay and Karkaŕn, which previously the Seljuks and the Georgians had taken from him. ${ }^{23}$ Using his close relationship with Sartakh, he succeeded in separating Khachen from Georgia and the Zak'arid Princes, as reflected in his title. Armenian inscriptions of Mama-Khatun, the daughter of Hasan, in Gandzasar, dated 1280 and 1286, mention his name as 'Prince of Princes, the Lord of Khachen.' In the inscription of Amaghu-Noravank', dated 1292, Mina-Khatun, the other daughter of Hasan, refers to her father as 'Great King.'24

In 1255, when Sartakh went to visit Möngke the Great Khan, Hasan Jalal joined him with his family, as is mentioned in the colophons of a Gospel in $1261 .{ }^{25} \mathrm{He}$ was granted enchü status by Möngke Khan in 1255. In return, he was obliged to perform military service every year. ${ }^{26}$ His position was secured by the marriage of his daughter to Bora Noyan, the son of Chormaghan. ${ }^{27}$ However, his daughter's marriage could not guarantee his life. In 1261, because of his failure to pay tax to the Mongols, and mainly because he had lost the protection of Sartakh who died in 1256, Hasan Jalal was tortured and killed by Amir Arghun in Qazvin. ${ }^{28}$

Another prince to whom Möngke Khan granted enchü status was Smbat Orbelian of the Siwnik' province, who visited Qara-Qorum in $1251 / 1252$. He went there to secure his land from Gontsa, the wife of the late Awag, who had infringed on his territory. In the narration

21 Ibid., 373.

${ }^{22}$ Kirakos Gandzakets'i, 1961:358. This was a master stroke of Hasan Jalal, to use the conflict between two Mongol powers in Iran and Russia. The Caucasus became an occasional arena of conflicts between the Il-Khanate and the Golden Horde from 1261 until 1266.

${ }^{23}$ Ibid., 1961:359.

${ }^{24}$ Orbeli, 1963:158; CIA, 1982:80.

25 Mathevosyan, note 258, pp. 311-312; Orbeli, 1963:155-156, 163 (note 26).

${ }^{26}$ Kirakos Gandzakets'i, 1961:269. Hasan Jalal had already participated with Baiju in the battle of Ch'man-katuk (Köse Dagh) between the Seljuks of Rüm and the Mongols in 1243 (Kirakos Gandzakets'i, 1961:283-284).

${ }^{27}$ Kirakos Gandzakets'i, 1961:391.

${ }^{28}$ Vardan Arevelts'i, 1991:152. Hasan Jalal's son At'abek brought his father's body to be buried in Jalal's ancestral cemetery at Gandzasar monastery (Kirakos Gandzakets'i, 1961:390-391). 
of his journey written by Step'annos Orbelian, Smbat, in return for a valuable precious stone (a ruby) presented to the Great Khan, retained the lands of Vorotan up to the boundaries of Borotna and Bghen, within which the Siwnik' court of Tat'ew was located. Besides this, he received Eghegis with the district of Vayots' Dzor; P'oghahanos; Urts, Vēdi with the valley of Ererawn, and many villages in Kotaik and Geghark'uni. ${ }^{29}$

Just before the vital shift of Mongol power from Baiju to Hülegü in Greater Armenia, Smbat Orbelian secured sovereignty over his dominions from the Zak'arid suzerains and the Georgian king by his second journey to Möngke Khan in $1256 .{ }^{30}$ The independence of the Orbelian prince was reflected in his title as 'King Smbat' in the inscription in Noravank in $1275 .{ }^{31}$ Smbat remained an important vassal of the Mongols in the time of the Il-Khans. He was sent by Hülegü Khan (r. 1256-1265), the first Mongol Il-Khan, to Ala Taq (Daŕn Dasht) to assist the latter in building a large royal palace. ${ }^{32}$

Having support from Hülegü Khan to implement his political goals, Smbat Orbelian encountered a serious opponent, Sadun Artsruni /Mankaberdeli (d. 1284), the atabeg and army commander of Awag. Seeing that Smbat possessed strong ambition, Sadun Artsruni decided to support Gontsa, the wife of the late Awag, who later married the Georgian King David (r. 1259-1270). ${ }^{33}$ While Smbat was in Qara-Qorum, Sadun replaced him as the guardian of Khoshak, ${ }^{34}$ the daughter of Awag and Gontsa, according to an anonymous Georgian source of the thirteenth century, and he was consequently recognised by the Georgian Court. ${ }^{35}$ Thus, Sadun became an influential figure in the political arena. Later, he was also recognised and honoured by Hülegü when he defeated the most valiant Mongol wrestler. ${ }^{36}$ The wrestling match at the Mongol Court was perhaps equivalent to the Christian knights' jousting tournaments. Being a successful wrestler in the ring meant being a good warrior in the field. Therefore, according to Grigor's perception, Sadun's victory

${ }^{29}$ Step'annos Orbelian, 1910:411.

${ }^{30}$ Ibid., 414.

${ }^{31}$ Kostaneants', 1913:118; Grigoryan, 1990:72, 75.

${ }^{32}$ Step'annos Orbelian, 1910:415.

${ }^{33}$ Melikset-bek, 1936:58.

34 The names of Khoshak and Sadun, the atabeg, are found in the inscription of the church of the Mother of God in Noratus (Avagyan, 1978:277).

${ }^{35}$ Melikset-bek, 1936:58.

${ }^{36}$ Grigor Aknerts'i, 1974:49. 
impressed the Mongols. This may serve as another example of an Armenian historian's insights into the development of MongolArmenian relations, as well as may illustrate Armenian lords' internal rivalry.

When Abaqa Khan (r. 1265-1282) succeeded to the Il-Khanid throne, Sadun befriended Shams al-Dīn Juvaynī, the șāhib-dīvān (executed in 1284), whom Khoshak, Sadun's protégée, married in $1269 .{ }^{37}$ After Hülegü's death, Smbat Orbelian lost his influential role in the political life of Armenia and Sadun became the favourite of Abaqa Khan. Moreover, he strengthened his position as atabeg of Georgia. ${ }^{38}$ The cities of Kars, Telavi and Bailaqan were separated from royal Georgian control and given to Sadun Artsruni. ${ }^{39}$

In order to re-establish the Orbelian House's authority, a brother of Smbat, Tarsaich, showed his loyalty to Abaqa Khan by participating many times in his battles..$^{40}$ On becoming regent in 1270, Tarsaich enthroned young King Demetrē II (r. 1270-1289) on the Georgian throne. ${ }^{41}$ Tarsaich was welcomed by Arghun Khan, who gave Demetrē all the territories of the Zak'arids, Gagets'i and Sadunians (Artsrunids).$^{42}$ Demetrē also appointed Tarsaich as atabeg of the Georgian lands. ${ }^{43}$

As can be seen, the above examples are cases of individual submission and of negotiations to ally with the Mongol Empire. Individual contacts between Armenian lords and either the Mongol Khan or his representatives during the early period of the Mongol presence secured Greater Armenia from major Mongol repression. Later, obtaining support from the Il-Khans, the Armenian lords once again secured authority over their Houses and lands.

\footnotetext{
${ }^{37}$ Step'annos Orbelian, 1910:418. Khoshak and Shams al-Dīn Juvaynī had a daughter Khuandze and a son Zak'arē (Rashīd al-Dīn, 1946:115-116; Melikset-bek, 1936:60; Babayan, 1969:175).

${ }^{38}$ Melikset-bek, 1936:60.

${ }^{39}$ Ibid., 60.

40 Step'annos Orbelian, 1910:423. The first wife of Tarsaich, Aruz Khatun, was

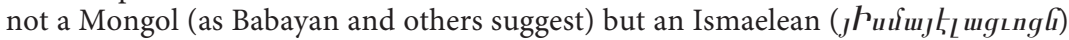
from Siwnik' (Step'annos Orbelian, 1910:416).

${ }^{41}$ Ibid., 426.

42 Ibid., 426.

${ }^{43}$ Ibid., 426.
} 


\section{State Submission and Its Development: The Armenian Kingdom of Cilicia}

If the princes of Greater Armenia dealt with the Mongols through their individual submissions to the Mongol Empire, the king of the Armenian Kingdom in Cilicia followed a different paradigm. The Armenian Kingdom in Cilicia held a unique historical position among the Christian states of the Levant, with its ties to the kingdom of Cyprus and principality of Antioch, and its very tense diplomatic relations with the Papacy. The attempt by Rome to force the Armenian Church to adopt Catholicism ${ }^{44}$ together with the direct threat from Egypt, made King Het'um I await the outcome of the battle in Köse Dagh or Ch'man-katuk (2uul-Guunnzl) with great interest. Once it was clear that the Sultanate of Rum had become a vassal of the Mongols, the Armenian Kingdom in Cilicia chose to begin negotiations with the Mongols prior to their advance on Cilician lands. In 1243, King Het'um sent his brother Smbat Sparapet, the Armenian commander from 1226 to 1276, along with his father, Baron Kostandin, to Baiju to propose their 'obedience. ${ }^{35}$ Baiju, who was advancing on Western Asia Minor, demanded that Cilician Armenia deliver to him the mother, wife and daughter of the Seljuk Sultan. ${ }^{46}$ For an account of this, we have the Chronicle of Smbat Sparapet, which states the details of the negotiations ${ }^{47}$ Fearing that the Mongols would progress onto his land, Het'um decided to hand over the Sultan's relatives. For its assistance to Outremer, Cilician Armenia was constantly under pressure from the Seljuks. The Syriac source of Bar Hebraeus reacts to this incident critically, saying: 'This most hateful and blameworthy act appeared in the sight of all kings as a thing which should never have been done. ${ }^{38}$ This act was the reason

${ }^{44}$ Bundy, 1987:227; Der Nersessian, 1947:15.

${ }^{45}$ Kirakos Gandzakets'i, 1961:285; Smbat Sparapet, 1868:649; Bar Hebraeus, 1932(II):408; Davit` Baghishets'i, 1956:346.

${ }^{46}$ Kay-Khusraw II, whose wife and daughter had sought refuge at the Armenian court at the time of the Mongol attack on Konya (Iconium) (cf. Cahen, 1969:138).

${ }^{47}$ When the talks began, the Mongols threatened Het'um's delegation with an ultimatum: Either the refugees of the Sultan should be handed over or the Mongols would devastate their country (Smbat Sparapet, 1868:649). Bar Hebraeus records this act differently, stating that Baron Kostandin (Constantine), the father of King Het'um, himself revealed the secret whereabouts of the Sultan's relatives to please the Mongols (Bar Hebraeus, 1932[II]:408).

48 Bar Hebraeus, 1932(II):408. Modern scholars discuss this act as well. Some accuse Het'um of breaching the code of eastern hospitality by surrendering his guests to Baiju (Gordlevskii, 1941:36-37). 
that some Armenian nobles rebelled against Het'um, joining the Seljuks and occupying a few Armenian fortresses. ${ }^{49}$ However, Het'um was determined to submit to the Mongols and, by handing over the Sultan's family and turning the Sultanate of Rūm into his irreconcilable enemy, he gained Mongol confidence. Het'um's foreign policy towards the Mongols started in Caesarea and paved the way for securing the survival of the Armenian kingdom in Cilicia. He reached an agreement whereby Cilician Armenia recognised its dependence on the Mongol Empire and was obliged to supply forces and provisions when necessary, and also to send a delegation to the Mongol court. The Mongol commander, in turn, promised to provide military protection against attacks by Muslim neighbours. ${ }^{50}$

According to this agreement, as Armenian sources claim, Baiju sent Smbat Sparapet to the Great Khan Güyük. ${ }^{51}$ Smbat Sparapet and his father Kostandin left Cilicia in 1246 for the Mongol court at Qara-Qorum, where Smbat, as the ambassador of the Armenian king, on his behalf made his submission to Güyük. ${ }^{52}$ The following story narrated in detail by Grigor Aknerts'i is an example of the Armenian historian's intention to explore the cause and the process of these events:

The pious and Christ-crowned king of Armenia, Het'um, with his father endowed with all wisdom, and [with his] God-fearing brothers and princes, entered council, and decided in their own minds to become subject to the Tatars and to pay taxes and xalan, ${ }^{53}$ and not allow [the Mongols] to enter their own God-created and Christian country, and so it happened. After they first saw Baiju, the commander of the Tatars, they confirmed treaties of love and submission. Then after that, they sent the brother of the King, the sparapet of Armenia, Baron Smbat to Sayin Ghan [Great Khan Güyük], who was seated on the throne of Chinggis Khan, and he went with God's blessing to see Sayin Ghan, because this Ghan was pious and very fond of Christians. ${ }^{54}$

49 Boase, 1978:25. The Armenian noble, Constantine of Lambron, sought to revolt against King Het'um and appealed to Kay-Khusraw. After the affirmation of Mongol protection over Cilician Armenia, Constantine took refuge with his Turkish friends (Cahen, 1968:270-271).

${ }^{50}$ Grigor Aknerts'i, 1974:31-32; Galstyan, 1976:31.

${ }^{51}$ Grigor Aknerts'i, 1974:31.

52 Smbat Sparapet in Galstyan, 1962:48; Davit' Baghishets ‘i, 1956:346.

${ }^{53}$ For xalan or qalan, a tax imposed on military service or on land use, see Chapter 4.

${ }^{54}$ Güyük had strong leanings towards Christianity, though he actually remained a Shamanist. 
Because of this, his race called him Sayin Ghan, which in their language means 'good Ghan.'

Sayin Ghan, seeing the Sparapet of Armenia, rejoiced very much because of his Christian faith, and even more because of the skilful and wise words, which the Sparapet of Armenia, Smbat spoke before him. And he [Sayin Ghan] made him a subject prince, and gave him a big yarlax $^{55}$ and golden p $^{6}$ ayzays ${ }^{56}$ and a Tatar xatun [wife], ${ }^{57}$ and this was for them [the Mongols] an expression of great love; whomsoever they [the Mongols] loved and respected, they gave in marriage a wife from among their honoured women. Thus, having bestowed great honour on the Armenian Sparapet, they sent him to his lands, to see Het'um, the Christian king of Armenia, ordering him [Het'um] to go himself and see him [Great Khan]. The pious King Het'um, seeing that Baron Smbat, his brother, was favoured with such honour and respected by the Ghan, rejoiced greatly, even more for having obtained documents freeing [from taxation] the country and monasteries and all Christians. ${ }^{58}$

There is an opinion that Smbat Sparapet did not reach Güyük Khan or the Mongol Court and that he only journeyed to Batu Khan of the Golden Horde. ${ }^{59}$ The reason for such an assumption is that the name Sayin Khan was usually associated with Batu Khan, grandson of Chinggis Khan. ${ }^{60}$ Therefore, it is concluded that Smbat Sparapet visited Batu Khan, since after Güyük's death, Batu Khan (r. 12271255), according to seniority among the Chinggisids, was in charge of all affairs until the enthronement of Möngke Khan. ${ }^{61}$ It is hard to agree with this view because the association between Sayin and Batu Khan does not mean that the other Khans could not be referred to as 'good' or Sayin, as was the case with Güyük Khan. ${ }^{62}$ From the cited episode, it is clear that Smbat Sparapet undertook his journey in 1246 , so it is very likely that he reached Mongolia before Güyük Khan's death in $1248 .{ }^{63}$ Secondly, the act of submission, which was

${ }^{55}$ Yarligh (Jarlig), a decree and a patent guaranteeing immunity ( $c f$. Doerfer, 1963(Vol. 4):153.

${ }^{56}$ Paiza, a metal tablet that served as a passport guaranteeing safe passage ( $c f$. Doerfer, 1963(Vol. 1):239.

57 By this Mongol wife, Smbat had a son called Vasil Tatar (Smbat Sparapet in Der Nerssessian, 1973:373, 374; Galstyan, 1958:xi).

${ }^{58}$ Grigor Aknerts'i, 1974:31-32; $c f$. R. Blake and R. Frye’s translation, 1954:313, 315.

59 Manandian, 1952:220.

${ }^{60}$ Grekov and Yakubovsky, 1937:103.

${ }^{61}$ Manandian, 1952:220.

${ }^{62}$ Cf. Cleaves, 1954:425.

${ }^{63}$ On foreign delegation at Mongol court in 1248, see Bar Hebraeus, 1932(Vol. 2):320-322; Carpini in Komroff, 1989:40-44. 
accompanied by the grants of yarligh and paiza, indicates a royal reception. ${ }^{64}$ Moreover, the giving of a Mongol woman in marriage and thus the creation of a vassal as son-in-law is more a royal gesture than that of a ruler of one of the Uluses, as was seen in the case of Awag Zak'arian. ${ }^{65}$ Chinggis Khan exercised this practice widely among his subordinates and subjects and thus pursued his diplomacy. ${ }^{66}$

Furthermore, a brief account of Smbat's journey to Mongolia can be found in a letter from Smbat to his brother-in-law, Henry I Lusignan of Cyprus, written in 1248 at Samarkand. ${ }^{67}$ According to Galstyan, this document is attributed to Smbat because the term Constable is used in the text for the sender of this message. It is known that, between 1226 and 1276, only Smbat Sparapet held the office of Gundstable (Armenian version of Constable) in the Armenian Kingdom of Cilicia. This letter is important for the detailed description of the places Smbat passed through during his journey to the Mongol court, which took him more than eight months in each direction. The letter also mentions political conditions in Mongolia, stressing that there had been several years of interregnum after the death of the present Khan's father (Great Khan Ögödei [r. 12291241]). ${ }^{68}$ Smbat says that since the Mongol princes were dispersed all over the kingdom, it took five years for them to gather and to crown the successor (Güyük Khan). ${ }^{69}$ In his letter, Smbat also points out a chapel built in front of the Great Khan's court, which allegedly

${ }^{64}$ There were cases when Mongol governors or residing princes granted paiza or yarligh to their vassals; however, the privileges they granted were more of economic concern, like taxation or compulsory labour. Thus, Sartakh granted these privileges to Hasan Jalal and to Nersēs, the kat'oghikos of the Caucasian Albanians, as well as to churches and mosques (Kirakos Gandzakets'i, 1962:358). Later, these unsanctioned acts by princes were abandoned by the central court by sending Amir Arghun to the region to bring order to the peripheries of the Mongol Empire (Juvaynī/Boyle, 1997:507). Hülegü was also dispatched to put an end to the provisional regime of the Mongol military rule and fiscal administration in the region (Rashīd al-Dinn, 1946:23).

${ }^{65}$ Although Prince Hủlegủ gave a Mongol wife to the Ismāîlī Imam Rukn al-Dīn Khur-Shāh, Hülegü sent the latter to the Mongol court in Mongolia for approval (Juvaynī/Boyle, 1997:721-722).

${ }^{66}$ MNT, 2004:78, 79, $84(\$ 235,238,248)$.

${ }^{67}$ Jackson, 2005a:98. Galstyan suggests that the letter was written in 1247 (Galstyan, 1962:64, 122-123 [note 155]).

${ }_{68}$ A Russian translation of Smbat Sparapet's letter to King Henry I Lusignan of Cyprus is found in Galstyan, 1962:64-66.

${ }_{69}$ Ibid., 66. 
indicates that the Khan and his people had become Christians. ${ }^{70}$ The most interesting part is the ending of his letter. He tells Henry that the Pope had sent his mission to the Khan inquiring whether he was Christian, at which the Khan told him that God knew it, and if the Pope wished to know, he should come and find out for himself. ${ }^{71}$

From this letter, we conclude that Smbat visited Qara-Qorum in 1248. Smbat's contemporary, Bar Hebraeus, in his Chronography clearly states that the Sultan of Rūm, Rukn al-Dīn, the Constable of Cilician Armenia, the Georgian crown princes, the senior and junior Davids and many other ambassadors from Asia and Europe went to Great Khan Güyük. ${ }^{72}$ Indeed, Smbat could possibly have met those who were in Mongolia after Güyük's coronation ceremony, such as the Papal ambassador Friar Plano Carpini, ${ }^{73}$ the Alamut delegation of Shihāb al-Dīn and Shams al-Dīn, ${ }^{74}$ the officials of Cathay (Northern China) and Korea, as well as amirs of Transoxiana, Khurasan, Iraq, Lur, Azerbaijan, Shirvan, the Sultanate of Rūm, and Georgia. Besides these, there were the Russian ambassador, Prince Yaroslav of Suzdal, the ambassadors of Aleppo, Mosul and Baghdad. ${ }^{75}$ They all had different purposes in visiting Qara-Qorum. Thus, in delivering the Pope's letter to Güyük Khan, Plano Carpini had three goals: First, to convert the Mongol Khan to Christianity, second to establish an alliance of friendship, and third, to assess the real threat to Europe posed by the Mongol Empire. ${ }^{76}$

The Cilician delegation came to the Great Khan to make a vow of peace and to become a subordinate state. They were well received

${ }^{70}$ Ibid., 66. This letter was presented to King Louis IX (1226-1270) on his arrival in Cyprus with the Seventh Crusade in 1248, who found it important enough to be forwarded to Pope Innocent IV (1243-1254) (Jackson, 2005a:98).

${ }^{71}$ Galstyan, 1962:66; Jackson, 2005a:98.

72 Bar Hebraeus, 1932(Vol. 2):320-321.

73 The Franciscan Plano Carpini left Lyons in April 1245. After travelling for fifteen months across Russia and the steppes of Central Asia, he reached the Imperial camp near Qara-Qorum in August 1246 to witness the Quriltai that elected Güyük to supreme power (Carpini in Komroff, 1989:40-41).

${ }^{74}$ Daftary, 1998:150.

${ }^{75}$ Carpini in Komroff, 1989:41.

76 The Great Khan Güyük, who had many Nestorian Christians among his advisers, received the Papal envoy kindly. However, after he read Pope Innocent IV's letter, requiring him to accept Christianity (the Latin text in Lupprian, 1981:179-181), he wrote a reply ordering the Pope to acknowledge his suzerainty and to come with all princes of the West to do him homage. This letter dated November 1246, written in Qara-Qorum in Persian, still exists in the Vatican archives (the Latin version in Lupprian, 1981:182-189) (Pelliot, 1923:3-30, 1924:225-335). 
and after a four-year journey, which also confirms that their journey was not to Batu Khan of the Golden Horde, they returned to the Armenian capital at Sis in $1250 .{ }^{77}$ Unfortunately, the Chronicle of Smbat Sparapet, despite being one of the most important Armenian sources for the history of Cilician Armenia, the Crusades and the Mongols, contains little information about his visit to Mongolia. ${ }^{78}$ It states only that 'in 697 [Arm.] (1248) I, Smbat Gundstable, went to the Tatars, and in 699 [Arm.] (1250), I returned to my brother, King Het'um. ${ }^{79}$ Galstyan agrees that it is obvious that the date of 1248 for Smbat's journey to Mongolia is a scribal error. ${ }^{80}$ This could well have been the date of his arrival in Qara-Qorum.

The success of the Cilician Armenian delegation in negotiating with the Mongols is a matter of interest. Through their intelligence network, the Mongols came to know well the internal and external preoccupations of the region. ${ }^{81}$ They knew that Cilician Armenia was a small Christian state that was in conflict with surrounding hostile Muslim sultanates and that the Armenians needed an alliance with those who were more powerful. On the other hand, the Sultanate of Rūm was still 'a stumbling block'on the way to the Mongol expansion beyond the borders of their empire, and having a loyal vassal state to rely on would be an advantage for the Mongols. This situation assured the success of the first stage of Mongol-Armenian negotiations.

The Great Khan sealed a memorandum with the Cilician delegates, ensuring that no-one would oppress the Armenian princes and that they might rule their kingdom without fear. However, there was one demand: King Het'um was requested to visit the Mongol Court personally. ${ }^{82}$ Therefore, following this 'invitation,' Het'um I visited the

77 Het'um Patmich', 1951:44.

78 Smbat's Chronicle is known as the Royal Chronicle or Cilician Chronicle (Der Nersessian, 1973:365).

${ }^{79}$ Smbat Sparapet, 1869:651. Armenian tradition says that Smbat was a wise Armenian Sparapet or Gundstable [Constable] (Grigor Aknerts'i, 1974:31-32).

${ }^{80}$ Galstyan, 1962:121(note 139). The discrepancy in dates between different editions of the Chronicle is studied in Der Nersessian, 1973. A manuscript of Smbat's Chronicle, dated 1315 and published in 1956 in Venice is used by Galstyan, 1962. The manuscript quoted in this study (no. 1308, the Library of San Lazaro) is less informative. There are several lacunae in this manuscript and many parts are missing (cf. Der Nersessian, 1973:353).

${ }^{81}$ Cahen, 1968:273.

82 Kirakos Gandzakets'i, 1961:366-367; Grigor Aknerts'i, 1974:31-32; Davit‘ Baghishets'i, 1956:346; Galstyan, 1976:31. 
court of the Mongol Khan in Qara-Qorum, making a journey of 3,500 miles in $1253 / 1254 .^{83}$ Qara-Qorum at that time was not only the capital of the Mongol Empire, but also a centre of diverse cultures and religions. It was the destination for ambassadors, travellers, missionaries and merchants. As has been said above, there were representatives of the Caliph, the Seljuk Sultan, diplomats from the Byzantine court and from other parts of the world. ${ }^{84}$ This was where the Armenian king had his meeting and dialogue with the Great Khan.

Many contemporary Armenian authors document this historical episode. Grigor Aknerts'i states that King Het'um went to Mongolia because of his love for the Christians and even more because of his concern for his own land. ${ }^{85}$ Vardan Arevelts'i confirms that He'tum made a victorious trip to Mongolia. ${ }^{86}$ Kirakos Gandzakets'i records the journey of King Het'um to Qara-Qorum with emphasis given to the historical geography of Central Asia along with zoology, mineralogy, aspects of Buddhism, folklore and tales. ${ }^{87} \mathrm{He}$ gives a list of sixteen localities through which Het'um passed, some of which are recorded only in his history. ${ }^{88} \mathrm{Het}$ 'um Patmich', the historian known as Hayton, provides extensive references to King Het'um's journey. ${ }^{89}$ Modern scholars have examined the routes of the journeys taken by King Het'um and other travellers of that period, such as Carpini and Rubruck. ${ }^{90}$ Attempts have been made to reconstruct the routes of these travellers. According to Boyle, the itinerary of the Armenian king through Uighur country along the right bank of the Syr Darya (Sîr-Daryā) seems to have been the normal highway for the medieval travellers. ${ }^{91}$

${ }^{83}$ Smbat Sparapet in Galstyan, 1962:49; Chahin, 1987:284. The journey of Het'um began at Sis and was sanctioned first by Baiju Noyan in Kars, who dispatched him to the gate of Derbent to Batu and Sartakh of the Golden Horde, who sent him to Mongolia (Kirakos Gandzakets'i, 1961:366-367). This relay dispatch of visitors via Baiju and then Batu Khan was implemented for the lords of Greater Armenia (Awag, Hasan Jalal and others) as well.

${ }^{84}$ Rubruck in Komroff, 1989:187.

${ }^{85}$ Grigor Aknerts'i, 1974:37.

${ }^{86}$ Vardan Arevelts'i, 1991:149.

${ }^{87}$ Kirakos Gandzakets'i, 1961:364-372.

${ }^{88}$ Gandzakets'i, 1961:366-372.

89 The History of the T'at'ars (1307) by Het'um Patmich' is also a remarkable ethnographic and geographical account (Bundy, 1987:223-235).

90 Bretscheider, 1887:164-172; Boyle, 1964:175-189.

${ }^{91}$ Boyle, 1964:177. 
The Mongol Great Khan Möngke received King Het'um (r. 12261270)..$^{92}$ According to Smbat Sparapet, the Mongol Khan in this reception 'fulfilled all requests of the Armenian King. ${ }^{.93}$ Kirakos makes a very clear point about this visit, stating that King Het'um remained in Möngke Khan's ordu for 50 days and the Mongol Khan gave the Armenian king a noteworthy edict (hpnyupunuly Ezuinuinp) that 'no one should harass him or his country.' Moreover, he indicates that Möngke Khan gave him a document ( $q \mathrm{hp}$ ) proclaiming freedom for the Church everywhere. ${ }^{94}$ Based on what these sources refer to, it is clear that the Cilician king made his submission to the Mongols.

However, it is interesting to find out what was requested by the King and what kind of document was given to him. If we assume that the 'edict' mentioned by Kirakos was a yarlikh (surely not a paiza, a metal tablet of authority), then what stands for document $(q h p)$ that was given to the Armenian king? Unfortunately, the contemporary Armenian sources do not solve this problem. The only source that highlights this issue is the early fourteenth century work of Het'um Patmich', known as Hayton.

In order to establish the degree of the plausibility for this source, it is worth taking an overview of related issues addressed in this work.

According to Het'um Patmich', Möngke Khan welcomed the Armenian king graciously on account of his voluntary submission and his desire to establish peace and an alliance with the Mongol rulers. ${ }^{95}$ The following is an extract from Het'um Patmich's history on the agreement sealed by both parties. It is said that the Armenian king put the following seven points to the Mongol Khan to be agreed: ${ }^{96}$

${ }_{92}$ Möngke, the eldest son of Tolui, was elected as the fourth Khan of Mongolia at the quriltai of 1251 . He decided to complete and consolidate the Mongol conquest of China and Western Asia respectively and to control matters directly in Iran and the Caucasus (Shirendyb, 1966:125-126). According to Het'um Patmich', the Armenian King Het'um was received in Almalik (Ameghek) by Möngke, not in QaraQorum (Het'um Patmich', 1951:45).

${ }_{93}$ Smbat Sparapet in Galstyan, 1962:49.

94 Kirakos Gandzakets'i, 1961:367.

${ }_{95}$ The partial translation of the source into Russian by Galstyan in 1962, is related to the agreement of Möngke Khan and King Het'um and based on the French original and the Latin version (Bundy, 1987:223-235).

${ }_{96}$ Het'um Patmich', 1951:45. This translation is by the author of this study from the Armenian version edited by Awgerean (cf. Galstyan, 1962:68). 
1. To be converted to Christianity and to be baptised; ${ }^{97}$

2. To establish peace and friendship between them; ${ }^{98}$

3. In all Tatar lands to establish Christian churches and to let the Armenians be free from any taxes and other oppressions; ${ }^{99}$

4. To take from the hands of the Turks the Holy Land and holy tomb and to give them to the Christians; ${ }^{100}$

5. To suppress the Caliph of Baghdad, who was the chief of a sect;

6. All Tatars to help them in time of need;

7. Every province of the lands of the Armenians, where the Turks ruled, to be given back. ${ }^{101}$

Some scholars see the purpose of this work and this agreement itself, especially the two clauses relating to the baptism of Möngke Khan and to the liberation of the Holy Land and its restoration to Christian possession, as sheer fantasy on the part of Het'um Patmich' who desired to 'set Western-Mongol relations on a new footing. ${ }^{102}$ This claim is based on the fact that such an agreement is not found in other contemporary sources, including the sources written by Armenian authors, like Kirakos Gandzakets' $i{ }^{103}$ However, as has been said above, Kirakos clearly referred to the visit and to a document being issued.

We can see that the existence of Het'um's document cannot be proved. However, the whole nature of the agreement brought into consideration by Het'um Patmich' may serve as an illustration of the development of Mongol-Armenian relations and it commands attention. Even if the terms of the agreement are wishful thinking on the part of Het'um Patmich', it remains interesting to know what his ideal objectives were. Since these objectives were in fact consistent with the actual course of the relationship between the Cilician Armenians and the Mongols in their early stages and whether these

\footnotetext{
${ }^{97}$ Friar William Rubruck met an Armenian monk called Sergius [Sargis] in Qara-Qorum, who was going to baptise Möngke Khan on the Feast of the Epiphany in 1254 (Rubruck in Komroff, 1989:138).

${ }_{98}$ The Russian translation of Galstyan gives us more details. The second point is translated as 'peace and friendship between Christians and Tatars' (Galstyan, 1962:68).

${ }_{99}$ This point has been translated 'In all land occupied by Tatars or those that will be captured later' in Galstyan, 1962:68.

100 Saracens instead of Turks (Galstyan, 1962:68).

101 'All lands dependant on the Armenian Kingdom and those captured by the Saracens and those under the Tatar's supremacy to be retained' in Galstyan, 1962:68.

102 Jackson, 1980:486.

${ }^{103}$ Ibid., 486.
} 
individual clauses existed or not, they can serve as an explanation of the relationship in the long term.

To confirm his account of events, the Armenian author gives details of the Mongol Khan's reaction to the Armenian King's offer. According to Het'um Patmich', Möngke Khan requested clarification of the clause (no. 6) that related to Mongol help when needed. Presumably, King Het'um I could not predict exactly when he would need Mongol help but obviously Het'um's aim was not merely to preserve his own kingdom and to obtain protection for the Christians under Mongol rule, but to enlist the Khan's help in freeing the Holy Land from the Muslims. ${ }^{104}$ If we follow Het'um Patmich', he says that the assurance given by Möngke's predecessor Güyük Khan was renewed and expanded. This implies that earlier, there was a certain agreement, possibly a memorandum, written or oral between Güyük Khan and Smbat Sparapet. Although almost nothing is known about the Mongol conditions, according to Het'um Patmich', Möngke promised to liberate the Holy Land, delegating these duties to his brother Hülegü, to whom Batu and other Mongol noyans stationed in Russia and Rūm should give assistance. Moreover, the Great Khan agreed to free Armenian churches and monasteries from taxation in territory under Mongol supremacy. ${ }^{105}$ In return, one can assume that the Mongols required from the Armenians all that they asked from their other vassals and allies: Obedience, tributes and support with provision and soldiers.

Mikaelean is possibly the first scholar to argue for the existence of such a document. He gives importance to the wider spectrum of this agreement, i.e., the issues of peace between the Christians and Mongols proposed by the Armenian King. ${ }^{106}$ Galstyan confirms that Het'um Patmich' used the sources that were available to him through his uncle, Smbat Sparapet, who led the first Armenian delegation to the Mongol court. He makes extensive references to this document in his Russian translation based on the French and Latin texts. ${ }^{107}$ In addition to this, it is worth noting that the baptism of Möngke Khan was not just in the mind of Het'um Patmich'. Rubruck mentioned that there was an attempt to baptise Möngke Khan in Qara-Qorum,

\footnotetext{
104 Het'um Patmich', 1951:45-46.

105 RHC/DA, 1869(Vol. II):297; Kirakos Gandzakets'i, 1961:367.

106 Mikaelean, 1952:310-314.

107 Galstyan, 1962:124-126 (note 164).
} 
in 1254, when he met the Armenian monk Sergius [Sargis]. ${ }^{108}$ We can therefore suppose that Het'um Patmich' was following the course of historical events and reflecting the common beliefs or ideas of the time. His aim was to provide evidence for the terms of the agreement being carried out and thus to confirm the submission of the Armenian monarch to the Mongols.

King Het'um returned home in 1256, encouraged by Mongol promises. On his way out and back, he passed through Greater Armenia, where many local princes and ecclesiastics welcomed him. ${ }^{109}$ It was the first time that a ruler of Cilicia had come into direct contact with the mother country. ${ }^{110}$ On his return, in October 1256, Het'um immediately exercised Mongol backing over the territories of the Sultanate of Rūm, near the city of Arakly. He went there with an army of up to 100,000 people, including all his relatives with their azats (nobles) in revenge for the devastation of the fortress and church of Murand by the Seljuks. ${ }^{111}$ Evidently, the Seljuks were no longer seen as a threat by the Cilician Armenians after the latter concluded their alliance with the Mongols. ${ }^{12}$

King Het'um tried to win the Latin princes over to the idea of a Christian-Mongol alliance but could convince only Bohemond VI of Antioch, who to some degree was Het'um's vassal through his marriage to his daughter Sybille. ${ }^{113}$ Despite the refusal of the Latin Christian states to follow Het'um's example and adapt to changing conditions by allying themselves with the new Mongol Empire, the Mongol-Cilician Armenian alliance was established and was beneficial as long as the Mongols stayed in power in the nearby region.

${ }^{108}$ Rubruck in Komroff, 1989:138-146.

${ }^{109}$ His visit to Mongolia was appreciated in Greater Armenia. On his way to Mongolia, King Het'um stopped in the village of Vardenis (Vayots' Dzor) with his host Prince Pŕosh Khaghbakian (Babayan, 1976:618).

${ }^{110}$ Der Nersessian, 1962:653.

111 Smbat Sparapet in Galstyan, 1962:49-50. An army of 100,000 seems to be exaggerated. The largest joint Mongol-Armenian forces did not exceed 60,000. The joint Armeno-Georgian forces that participated in the Mongol campaigns in Syria did not exceed 30,000 men (see Chapter 7).

${ }_{112}$ Mikaelean, 1952:326.

113 Boase, 1978:25; Der Nersessian, 1969:49. 
While Het'um was gaining some results from his cooperation with the Mongols and regaining some fortresses that had been taken from him by the Seljuks, the antipathies that existed between and within the noble families in Greater Armenia came to a climax. This situation, which was extremely common in all subjugated lands, suited the Mongols' policy, since they were seeking loyal vassals on the one hand and aimed to disrupt the unity of the Armenian lords on the other. Thus, to punish Awag Zak'arian for his escape, his land was given to his cousin Shahnshah. ${ }^{114}$ By incorporating certain lords into their own court and administration, the Mongols, following their imperial policy, boosted the territorial and political ambitions of the Orbelians and Artsrunids at the expense of the Zak'arids and the Georgian Bagratid dynasty in the 1260s. Moreover, the royal Georgian House was affected greatly by enthroning two Davids. Previously, Queen Rusudan had fled to Abkhazia and then to Swanetia with her young son David Narin (Junior), whom she had placed on the throne. ${ }^{115}$ She sent David on her behalf to submit to Batu Khan (r. 1227-1255), who was in control of the Mongol troops in Russia and the Northern Caucasus at that time. ${ }^{116}$ Batu Khan sent David Narin to the Great Khan. In 1246, the Mongols brought Bagratid David Ulu (Senior), the illegitimate son of the Georgian King Lasha, from Caesarea to the throne in Tiflis. ${ }^{117}$ They sent him to the Great Khan as well. They were both received by Güyük Khan, who decreed that they should rule the kingdom in turn, first David (1247-1270, from 1259 he reigned over the eastern part of Georgia), the son of King Lasha as the elder of the two; then, following his death, his cousin David Narin (1245-1293, from 1259 he ruled the Kingdom of Imereti), son of Rusudan. The Great Khan divided the treasury of the kingdom into three parts: the priceless throne and the stunning crown allegedly belonging to Khosrov, father of Trdat the Great, the king of the Armenians, which had fallen to the Georgians, would be

114 Kirakos Gandzakets'i, 1961:265.

115 David (Narin) was a son of the Georgian Queen Rusudan and the Seljuk Prince of Erzerum, a grandson of Kilij Arslan II, who embraced Christianity on his marriage in 1224 (Toumanoff in Hussey, 1966:626).

116 Kirakos Gandzakets'i, 1961:315.

117 Grigor Aknerts'i, 1974:33; Orbelian, 1910:420-421; Rusudan sent David to her daughter who had married Ghiyāth al-Dìn, the Sultan of Rūm, where he was imprisoned (Kirakos Gandzakets'i, 1961:315-316. 
sent to the Khan; and the remainder would be divided between the two Davids. On their arrival, with the assistance of Awag, David Ulu, the son of Lasha, was placed in Tiflis, and the other one in Swanetia. ${ }^{118}$ Hence, the Mongols were able to defuse the opposition by taking advantage of the internal strife within the kingdom. ${ }^{119}$

The severe taxation policy and the arbitrary nature of Mongol rule along with its rigorous requirement to participate in Mongol campaigns by acting as human shields were the key reasons for the Georgio-Armenian princes' rebellion of $1249 .{ }^{120}$ According to the Georgian sources examined by Melik'set-bek, in 1249, the GeorgioArmenian princes, including Shahnshah, Vahram Gagets'i and many others along with their troops, gathered in Tiflis in order to convince King David (Ulu) that with such a great army, they could attack the Mongols suddenly and exterminate them. ${ }^{121}$ Prince Awag intercepted this plot. On discovering this rebellion, the Mongols arrested the participants. The Mongols demanded that the rest of the princes demonstrate their loyalty to the Khan. King David and the other princes responded quickly to Chaghatai Noyan's call but in accordance with their custom, the Mongols bound their hands and feet tightly with thin cords and kept them for three days in punishment for their rebellious plan. ${ }^{122}$ Even the mother of Prince Awag came to Chaghatai to assure him of her son's loyalty. The Mongols spared the life of the king and some princes in exchange for a ransom paid by Awag. However, they killed many who had rebelled and some that had not rebelled, especially in the land of the Georgians. ${ }^{123}$ The Mongols also captured King David (Narin) the son of Rusudan, probably because of his rebellion. He was imprisoned in the province of Haband, from where he escaped to Swanetia, where he stayed until his death in $1293 .{ }^{124}$ The revolt was suppressed by Noyans Baiju and Angurag. ${ }^{125}$

${ }_{118}$ Ibid., 317.

119 The same practice of joint rule was introduced in Anatolia between two sons of Kay-Khusraw. Such arrangements of division in ruling by the Mongol government were typical in other provinces of the Il-Khanate (Melville, 2009:51-101).

${ }^{120}$ Grigor Aknerts'i, 1974:35.

${ }^{121}$ Melikset-bek, 1936:56.

${ }_{122}$ Kirakos Gandzakets'i, 1961:319-320; Grigor Aknerts'i, 1974:36.

123 Vardan Arevelts'i, 1991:148.

124 Step'annos Orbelian, 1910:406-407.

${ }^{125}$ Melikset-bek, 1936:57. 
In 1251, before King Het'um set out on his journey to Mongolia, the Armenian Catholicos Kostandin (1221-1267), hoping to gain from this diplomatic mission strong backing for Cilician Armenia to resist the Mamluks and the Seljuks, sent a letter to Greater Armenia asking people to abstain from rebelling against the Mongols and their governors. ${ }^{126}$ This appeal worked; however, the next revolt of the Armenian princes occurred in 1259-1261. In 1259-1260, a Mongol tax called qubchur was introduced in Georgia and Armenia, which became a heavy burden for the Caucasian lords. Some of them had to mortgage their estate to pay this tax. ${ }^{127}$ This led to a rebellion of the princes against whom the Mongol ostikan (governor) Arghun conducted a military operation. ${ }^{128}$ Since Amir Arghun failed to catch the Georgian King David who fled to Abkhazia because of the heavy burden of taxes along with other impoverished princes of the provinces, he mercilessly ruined many Georgian provinces. ${ }^{129}$ According to Mkhit'ar Ayrivanets'i, in 1261, Arghun destroyed much of Georgia. ${ }^{130}$

Nevertheless, the revolt of 1259-1261 also had another aspect. Although it started as a rebellion against the conquerors, later it became a conflict among the lords as well. Smbat Orbelian's ambition for the subjection of the territories of Awag and his vassals, the Pŕoshians and Vachutians, and his exploitation of Amir Arghun's patronage brought the discontented lords to Gontsa, the Queen of Georgia. In the absence of Smbat, they attempted to encroach upon his lands and rights. On completing his journey to Mongolia and obtaining support from Amir Arghun, Smbat Orbelian put an end to this revolt. Gontsa was drowned on the orders of Hülegü Khan. ${ }^{131}$ Although Prince Shahnshah was freed for a ransom, his son Zak'arē was killed. ${ }^{132}$

Even later, the local conflicts continued. At the beginning of the 1270s, after the death of Smbat Orbelian, the Khaghbakian-Pŕoshians decided to separate their own province of Ernjak in Vayots' Dzor, which had been taken by the Orbelians, from the diocese of Siwnik'. By that time, Prosh Khaghbakian, the founder of the Pŕoshian lin-

\footnotetext{
126 Kirakos Gandzakets'i, 1961:293-310.

127 Ibid., 293-310. For qubchur tax, see Chapter 4.

128 Kirakos Gandzakets‘i, 1961:389.

129 Kirakos Gandzakets`i, 1961:389-390.

130 Mkhit'ar Ayrivanets'i, 1860:68.

131 Step'annos Orbelian, 1910:418.

132 Kirakos Gandzakets'i, 1961:391-393; Vardan Arevelts‘i, 1991:152.
} 
eage, had already strengthened his position and his House through Hülegü by participating in the Mongol conquest in the Middle East. He wanted to reinstate the episcopacy of the Khaghbakians, including Ernjak. ${ }^{133}$ However, the struggle, which concerned religious and economic issues, ended in favour of the Orbelians who were backed by the Mongol governors. ${ }^{134}$

Despite the relative dearth of sources, several instances of individual contacts between the Armenian lords and the Mongols can be traced. As has been shown, there was very close collaboration between Awag Zak'arian through Chormaghan and Güyük Khan, Hasan Jalal through Sartakh and Möngke Khan, Smbat Orbelian and Möngke Khan and Hülegü, and Sadun Artsruni and Hülegü and Abaqa Khan. These partnerships paid significant dividends for both the Armenians and the Mongols. Geographically, the relationships established between the Greater Armenian lords and the Mongols, had a tendency to develop from north to south. This can be explained by the fact that the relationships between the Armenian lords and the Mongols were more intense in the northern territories of Greater Armenia during the reign of the Great Khans. The presence of Batu Khan and his offspring in the territories to the north of Greater Armenia and their supervision of the Caucasus was a strong motive for keeping the Zak'arids in power before the establishment of the Il-Khanate. By the time the Mongols settled in Iran, the influence of the northern Armenian Houses had faded and the southern Houses in Khachen and in Siwnik' had become stronger. The southern Armenian lords benefited from being closer to the centres of the Il-Khanate. The shift of Mongol power from north to south reflected the transfer of power in Greater Armenia as well. This situation suited the Mongols too because they would need reliable and loyal vassals to pursue their further imperial goals.

\section{Other Factors Influencing Mongol-Armenian Relations}

Mongol-Armenian affairs were influenced by many other factors. One of the methods of maintaining good relations was the use of diplomatic marriages between the Caucasian nobility and the Mongols. The sources mention several examples where the Armenians

133 Hovsep'ean, 1928:16-17, 36-45; Babayan, 1969:215.

134 Step'annos Orbelian, 1910:364-365. 
took Mongol spouses. Awag was given a Mongol wife by Güyük Khan. ${ }^{135}$ Bora Noyan, the son of Chormaghan was married to the daughter of Hasan Jalal. ${ }^{136}$ Smbat Sparapet was given a Mongol wife and had a son by her called Vasil Tatar, who died in a battle with the Sultan of Egypt in 1269. ${ }^{137}$ The daughter of the Georgian King Demetrē was married to Bugha Noyan. ${ }^{138}$ These marriages facilitated support for Mongol rule and also served the Armenians' cause.

It would be very useful to find some contemporary ecclesiastical sources permitting the Armenian aristocracy to have a polygamous marriage to a Mongol as well as a Christian wife. The only observation that can be made is that the state of being a vassal or being under the military and political dominion of the conquerors, meant that the Armenian Church had to deal with this phenomenon through unwritten rules or regulations, since it allowed the baptising or knighting of the children born from such marriages, as is illustrated in the case of the son of Smbat Sparapet. ${ }^{139}$ Vasil Tatar was buried in September 1269 in the holy Monastery of Mlich'. ${ }^{140}$

According to the statements of Armenian historians, the monks and lords of Greater Armenia were also employed by the Mongols as their diplomats and secretaries. Thus, in a village called Lorut, south of the Tavush fortress, Molar Noyan captured the cleric Kirakos Gandzakets' $i$, who was to serve his secretarial needs, writing and reading letters throughout the Summer of $1236 .{ }^{141}$ In 1246, Lord Vahram Gagets'i was sent to Caesarea to represent Baiju in negotiations for the liberation of David, the son of King Lasha, from prison. ${ }^{142}$ The priest Barsegh was known as Batu Khan's emissary (ntuuuuq); he accompanied King Het'um (r. 1226-1270) on his journey through Caucasian Albania and the Gate of Derbent to Batu's headquarters. ${ }^{143}$

135 Kirakos Gandzakets'i, 1961:263.

136 Ibid., 391.

137 Smbat Sparapet in Galstyan, 1962:9, 122. Vasil Tatar was baptised and knighted in 1265 and was a general-in-chief of the Cilician Armenians (Smbat Sparapet in Der Nerssessian, 1973:373, 374).

138 Step'annos Episkopos, 1951:48-49.

139 Smbat Sparapet in Der Nerssessian, 1973:373, 374.

140 Smbat Sparapet in Galstyan, 1962:64.

141 Kirakos Gandzakets'i, 1961:243-252. Vanakan Vardapet and Kirakos Gandzakets'i were in Mongol captivity for one year (Davit' Baghishets'i, 1956:346).

142 Grigor Aknerts'i, 1974:33.

143 Kirakos Gandzakets'i, 1961:366, 370; Smbat Sparapet in Galstyan, 1962:49. 
The Armenian Church supported the collaboration of the Armenian lords with the Mongols. Undeniably, the fact that some of the Mongol chiefs had Nestorian Christian wives assisted the Christians in the Caucasus. Thus, in 1242, the help of Altuna Khatun made possible the return of Nersēs, the Catholicos of Caucasian Albania to his seat. While Nersēs was hidden in the monastery of Khamshi in Awag's territory, Altuna Khatun invited him to her camp in Mughan. With Awag's permission, he visited her on a special day when she was celebrating the weddings of her two children. Altuna Khatun asked her two brothers, both Christians and newly arrived from Mongolia, to honour the Catholicos and afterwards she gave Nersēs the document with the altamgha (red seal), proving his immunity from any Mongol harassment. ${ }^{144}$ In 1247, when Catholicos Kostandin (1221-1267) of Cilicia saw the ruins of Armenia and the sufferings of the people, he circulated canonical orders throughout the districts of Armenia to all bishops, monks and princes to bring church affairs into order. He sent gifts of silk clothes, expensive mantles and quantities of gold for the monastery of St. T'adeos in Greater Armenia. After the construction work had been completed, the monastery was opened with the assistance of the Mongol commander, Angurag Noyan, who had Summer quarters near this monastery. ${ }^{145}$ In the early 1250 s, Smbat Orbelian received a decree that freed all the churches and priests of Armenia from taxes. With the encouragement of General Baiju's Christian wife, Smbat renovated Siwnik's religious seat, Tat'ew. ${ }^{146}$ The Armenian monk Sergius (Sargis), who played a very active role in the court of Möngke Khan in Qara-Qorum, even attempted to baptise the Mongol Khan in 1254. ${ }^{147}$ In 1264, Hülegü received some Armenian clerics, including Vardan Vardapet, in order to explore the disposition of the ecclesiastics towards the Mongol policy. ${ }^{148}$ These examples of support for Christianity show that both in Greater Armenia and in Cilicia, the Mongols dealt sufficiently with Christian issues. They illustrate the circumstances in which Mongol-Armenian collaboration might be carried out more easily.

\footnotetext{
144 Kirakos Gandzakets'i, 1961:290-292.

145 Ibid., 311-312.

146 Step'annos Orbelian, 1910:412.

147 Rubruck in Komroff, 1989:138-146.

148 Vardan Arevelts'i, 2001:204-209.
} 
It is important to stress that the Armenian sources that are at our disposal can reveal two different patterns of submissions by the two different Armenian territories to the Mongols. Greater Armenia was conquered by the Mongols but Cilician Armenia surrendered voluntarily. In both cases, nevertheless, they became vassals, with different obligations.

However, the Greater Armenian lords decided to deal with this new pressure by taking individual approaches and responsibilities. The surrender of Greater Armenia proceeded by individual and separate territorial submissions. With regard to this, it is worth stressing that these individual submissions were made in a timely way, before the Mongols devastated the whole country, giving them a chance to safeguard most of the Armenian lands.

As a result, the use of Mongol power guaranteed several Armenian lords not only security in their own lands, but also an extension of their patrimony by removing their local opponents from the political arena. If the first rebellion in the Caucasus was against the repression of the Mongols, the second can be considered an internal clash between lords who were under the Georgian crown and those princes who were under Mongol patronage. In the long run, this policy of the local princes suited the Mongols. They preferred to have their own suzerainty over the Armenians and to see the Armenian lords attached to them rather than to the Georgian court, ensuring that the Georgio-Armenian lords were more disunited.

The strategy of the Greater Armenian lords towards the Mongol presence was cooperative rather than confrontational. In fact, the assistance given by Awag Zak'arian to Chormaghan and Güyük Khan; Hasan Jalal to Sartakh and to Möngke Khan; Smbat Orbelian to Möngke Khan and Hülegü; and Pŕosh Zak'arian and Sadun Artsruni to Hülegü and Abaqa Khan illustrate effective Mongol-Armenian partnerships. ${ }^{149}$

Seeing the shift of power in Asia Minor and being influenced by the example of Georgio-Armenian lords, the Armenian Kingdom of Cilicia also made a decision to submit before any Mongol intrusion into their land. The whole state thus became a Mongol vassal. In order to achieve the status of an ally, the Cilician monarch personally visited the Mongol Khan. This visit would later have strong political

149 There were 'duos' of Mongol and Cilician rulers as well (see Chapters 5, 6 and 7). 
implications for his country. Actual historical events show that this decision by the Cilician Armenians to express their loyalty to the Mongol authorities and Great Khans was just in time.

If we believe the Armenian sources, the submission was ensured by the establishment of a certain agreement between the Mongols and the Cilician Armenians. Although the existence of such a document is questionable, the whole nature of the 'agreement' illustrates the possible course and objectives of Mongol-Armenian relations and serves as an explanation of the relationship in the long term. 